\title{
Tourism demand and atmospheric parameters: non-intrusive observation techniques
}

\author{
M. B. Gómez-Martín ${ }^{1, *}$, E. Martínez-Ibarra² \\ ${ }^{1}$ Department of Physical Geography and Regional Geographical Analysis, University of Barcelona, Montalegre 6, \\ Barcelona 08001, Spain \\ ${ }^{2}$ Laboratory of Climatology, University of Alicante, Campus de San Vicente del Raspeig, s/n, Apdo. Correos 99, \\ Alicante 03080, Spain
}

\begin{abstract}
In this study, we used images from webcam cameras and Argus video systems to examine how the behaviour of sun and beach tourists in Spain was influenced by the meteorological weather conditions. We applied a qualitative visual count method, which involved creating a bank of images and undertaking a classification of the density of use at each observation point. Thus, each image was assigned a density-of-use level. These results were then correlated with a range of meteorological variables and the physiological equivalent temperature (PET). Atmospheric conditions do have an impact on the behaviour of sun and beach tourists, and our study shows that the density of use of the beaches in Spain is controlled by solar radiation (the aesthetic facet) and the maximum temperature and PET (the comfort facet). The optimal thresholds of these meteorological variables for going to the beach were as follows: a maximum temperature between 28.83 and $31^{\circ} \mathrm{C}$; a maximum PET between 34.5 and $38.8^{\circ} \mathrm{C}$; a percentage of solar radiation at 13:00 $\mathrm{h}$ of at least $50 \%$; a wind speed at $13: 00 \mathrm{~h}$ of $<8 \mathrm{~m} \mathrm{~s}^{-1}$ (or, at the most, $<10 \mathrm{~m} \mathrm{~s}^{-1}$ ); and no rainfall or, at the most, $<1 \mathrm{~mm} \mathrm{~d}^{-1}$ or a rainfall event with a duration of $<60 \mathrm{~min}$. The application of these thresholds for determining the degree of use of beaches during the year should lead to more accurate forecasts of the calendar of the tourist season and ensure that the basic tourist resources provided for beach tourism are managed more effectively during these periods, including the provision of services and safety facilities.
\end{abstract}

KEY WORDS: Sun and beach tourism - Atmospheric conditions · Tourism demand - Webcams · Spain

Resale or republication not permitted without written consent of the publisher

\section{INTRODUCTION}

Although tourism-demand studies are numerous and varied and have acquired importance in the field of tourist research (Crouch 1994, Pack et al. 1995, Witt \& Witt 1995, Melenberg \& Van Soest 1996, Smeral \& Witt 1996, Eymann \& Ronning 1997, Lim 1997, Wang 2004, Song \& Li 2008), those that analyse possible links between tourism demand and atmospheric conditions remain limited and scarce (Lise \& Tol 2002, de Freitas 2003, 2009, Hamilton et al. 2005, Agnew \& Palutikof 2006, Coombers et al. 2009, Scott \& Lemieux 2009, Álvarez-Díaz et al. 2010). As a result, there is considerable uncertainty concerning the definition of the study dimensions of tourism demand in relation to atmospheric conditions and, consequently, in establishing the methods needed to understand this demand. The aim of this article, therefore, is to reduce the uncertainties in this line of research by analysing 1 of 6 possible dimensions of tourist behavior (see Table 1).

These study dimensions of tourist demand become more relevant and more marked depending on the extent to which they interact with each other. For example, the behaviour dimension, understood by de Freitas (2009) as the manifestation of how an individ- 
Table 1. Study dimensions of tourist demand in relation to atmospheric conditions

\section{Dimension of demand}

Definition

\section{Perception}

Understanding of atmospheric conditions (including perception of the weather and/or of the different variables of which it is comprised, such as temperature, sunshine, precipitation, etc.) or of a specific atmospheric phenomenon or event (for example, perception of climate change or of an extreme weather event) as perceived by the senses. Perception is selective and influenced by various mechanisms and factors that explain (or help to explain) why individuals perceive things differently and why some phenomenon are perceived by some but go unnoticed by others.

\section{Attitude}

Set of proclivities, preconceptions, ideas, fears, threats and convictions that induce the individual to react in a given way to certain atmospheric conditions and future climate scenarios. In the attitudinal dimension, the affective component outweighs the cognitive.

\section{Preferences}

Predilection or inclination for certain weather conditions or conventions in response to given atmospheric questions or problems. Includes the possibility of establishing a rank order.

\section{Motivation}

Set of factors capable of inducing, maintaining and directing the tourist's behaviour towards a given objective. Here, it is interesting to know the importance attached to climatic and meteorological features in the decision-making process and in the tourist-consumer's act of purchasing.

\section{Opinion}

A more static condition, representing the holding of an evident and reasoned mental standpoint regarding a given matter or person. It does not connote a disposition to act. In this dimension, the cognitive component outweighs the affective.

\section{Behaviour}

Set of motor responses to both internal and external stimuli, potentially including responses related to the climate, meteorological conditions, changing weather scenarios, etc.

ual reacts, adapts or readjusts to a determinate situation or circumstance, is affected by experience. The individual learns from experience, and this experience affects behaviour. At the same time, the cumulative effect of experiences changes perception, and consequently, the response changes. Perception is determined by motivations, and in parallel, perception conditions attitudes, which in turn also affect behaviour.

Beyond conceptual questions, tourist behaviour is affected by factors related to meteorological condi- tions, among others (Hu \& Ritchie 1993, Crouch 1994, Butler 2001, Gómez-Martín 2005). The extent of this influence is determined by the degree of sensitivity of the tourist activity to the weather and climate, in general, and/or to given atmospheric conditions, in particular. Beach tourism is one of the activities with the greatest degrees of sensitivity to the weather and climate. This paper presents the findings of a study of the behaviour of beach tourists in relation to various atmospheric parameters using webcam images and video systems as the main sources of information. The determination of the temporal and spatial distribution of tourist habits (seen as motor responses to the stimuli of the weather and climate) and possible modifications of this behaviour as a function of the variability in atmospheric conditions should be of use in short-, medium- and long-term coastal management plans. Thus, knowing the number of beach users or the density of a beach's use are important parameters, both for proper beach management and for defining indices of coastal environmental quality (Guillén et al. 2008). The appropriate design of beach access facilities, showers, lifeguards, cleaning and other services is determined, to a great extent, by the number of people on the beach throughout the day and the distribution of this use in relation to the day of the week, holiday periods and weather conditions, to mention just a few aspects. In relation to the weather, an understanding of the links to the atmospheric conditions, which facilitates day-to-day beach management, can also be useful for introducing adaptations to reduce vulnerability to impacts from climate change.

Below, we present findings from research into the behaviour (in particular, the density of use) of beach tourists in relation to atmospheric weather conditions, based on information provided by webcam images and video systems for a number of locations on Spain's Mediterranean coast. First, we present a state of the art study of the research that has been conducted into the behaviour of tourists in relation to different meteorological variables, on the one hand, and of the research that uses these new tools to capture quantitative and qualitative data related to tourism, on the other. Then, we describe the study area, the methodology used, our main results and the conclusions that can be drawn from them.

\section{LITERATURE REVIEW}

Behaviour, understood as the set of motor responses to both internal and external stimuli, has 
been widely examined in tourism studies, in particular from a marketing perspective (Moutinho 1987, Kotler et al. 1996, Pizan \& Mansfeld 1999, Swarbrooke \& Horner 1999, Pearce 2005). However, as de Freitas (2003) noted, research into the role played by atmospheric stimuli in the behaviour of tourists is not very extensive, despite the importance it might have for the correct management and planning of tourist activity. De Freitas (2003) identifies 2 possible ways to examine behaviour of tourism demand in relation to the weather and climate. The first method evaluates conditional and anticipated behaviour using surveys and interviews that seek to determine how individuals react to certain atmospheric stimuli (e.g. Adams 1973). The second method evaluates actual behaviour, either using various indicators (such as the number of visitors, hotel occupancy rates, etc.) or on-site observations. In relation to these indicators, a number of studies have presented explanatory models based on the correlation between behaviour measured in terms of tourist flows and various atmospheric variables, among others. On occasions, the models have been extrapolated to make forecasts of future behaviour under different climate-change scenarios (Lise \& Tol 2002, Hamilton et al. 2005, Bigano et al. 2006).

As for on-site observations, several studies have been undertaken in recent years that exploit the application of new information and communication technologies. The potential offered by systems of observation based on the use of digital camera stations that transmit information via Internet has been used for more than 2 decades to undertake studies of various environmental problems (Holman et al. 1993, Holland et al. 1997) and, in particular, for studies on the thermal environment in outdoor public spaces and the use of such spaces (Nikolopoulou et al. 2001, Thorsson et al. 2004, 2007, Eliasson et al. 2007, Lin 2009). The application of this technology to tourism research has, however, been more recent, with Timothy \& Groves (2001) being the first to explore the possibilities afforded by new technologies. In their study, based on the analysis of 300 webcams consulted via Internet, the authors provided evidence of the possibility of extracting information from the images about the spatial and temporal behaviour of the individuals observed. This information can be related to a multiplicity of factors, including atmospheric conditions, and is particularly useful because of its high temporal resolution, its adequate spatial resolution and the high number of sample points that can be considered. In the case that concerns us here, the high temporal and spatial resolution may allow us to observe the different ways in which individuals adapt, adjust or react to different atmospheric conditions (de Freitas 2009). Sun and beach tourists may show a wide range of responses to the various atmospheric conditions: pursue, or not, a given activity; change the activity to suit weather conditions so as to maximise enjoyment of the outdoor experience (swim more or less, extend or reduce the length of stay, etc.); avoid areas with unfavourable conditions (look for sun or shade, look for areas more or less close to the water or choose the holiday destination according to the weather); use structural or mechanical aids (umbrellas, wind breaks, hats, shelters, etc.); adjust thermal insulation of the body (clothing); or adopt passive acceptance (de Freitas 2009).

The potential of the application of these systems of observation for tourism is reflected in a number of recent studies. For example, using webcam images, Kammler \& Schernewski (2004) examined the variation in the spatial and temporal demand of visitors to a beach in northern Germany and the implications for the management of beach tourism. Jiménez et al. (2007), drawing on information from various Argus video-cameras, proposed Coastal State Indicators (CSI) for use in different aspects of the recreational management of beaches examined in a number of case studies. Similarly, Guillén et al. (2008) monitored 2 city beaches in Barcelona (Spain) and established daily, weekly, seasonal and interannual user distribution patterns based on a consideration of certain external factors, including temperature and wind conditions. Martínez-Ibarra (2010) proposed a series of weather types for evaluating the touristclimate aptitude for sun and beach tourism on the Alicante coast. Optimal weather-type thresholds are established based on an analysis of the daily occupation of the Levante Beach in Benidorm (Spain), calculated with the support of webcam images. Likewise, Moreno et al. (2008) analysed the influence of various weather conditions on levels of occupation of beaches in Zandvoort (The Netherlands) and establish optimal thresholds for some the variables under consideration. De Freitas (2009) went beyond the simple observation of use or attendance and analysed other aspects of the behaviour of sun and beach tourists in the southeast of Queensland (Australia), relating them to an index of thermal sensation. $\mathrm{He}$ concluded that the attendance or density of use of tourist places is a partial measure of tourist behaviour that needs to be complemented with the observation of other responses, such as the length of the stay, location, use of elements of defence or protection and so on. 


\section{STUDY AREA AND METHODS}

The Mediterranean is the world's leading region for sun and beach tourism (WTO 2010b). Within this region, the Spanish coast has the highest indices of use (WTO 2010a) and quality (Foundation for Environmental Education; www.fee-international.org/en). The quality of its resources linked to the introduction of quality criteria in the management of its beaches, together with the permanent provision and renewal of facilities and the integration of complementary activities of leisure and relaxation, make Spain's Mediterranean sun and beach resorts highly competitive.

We collected images obtained from webcams and video systems set up at 19 sampling stations on the coast of the Iberian Peninsula, primarily in the Mediterranean region. The sampling stations selected (highly frequented tourist beaches) can be considered important laboratories for tourism climatology (Martínez-Ibarra 2010), and observation using webcams and video systems is a non-intrusive method enabling researchers to study the behaviour of individuals without inducing changes in the activity being studied.

Although the installation of systems of this type has become widespread in recent years, they have more than one use (surveillance and security, coastal parameterisation, load capacity evaluation, marketing, etc.) and are managed by various organisations (e.g. security firms, research bodies and local and regional authorities), which results in considerable heterogeneity in terms of image quality, angles of observation, periodicity, continuity of the series, etc. This means there is a need to undertake a careful selection of the material so as to work with homogenous information that is comparable and can be extrapolated to other places of analysis. The beaches selected for the Mediterranean coast are shown in Fig. 1 and Table 2. We also chose Gorliz on the Cantabrian coast, as an example of a 'cold' beach. The beaches were studied between 1 July and 20 October 2009 at midday, the period of maximum recreational activity. The duration of this study eliminates the role of shoreline dynamics in determining the use and exploitation of the beaches, given that the surface area of the beach above the waterline might change over the years.

The beaches selected have a number of characteristics in common reflecting their classification as tourist beaches (see Table 2). They are, above all, fine sand beaches of sufficient width and length to attract tourists. The beaches are suitable for bathing, with gentle bathymetric gradients and wind and wave regimes that ensure the safety of swimmers. The beaches lie within either major recreational or urban centres, which provide numerous and varied commercial services and hotel facilities. They all have a promenade that is easily accessible to potential users and are equipped with all of the facilities that ensure the optimum development of beach tourism.

To analyse the level of occupancy on the beaches selected, we developed a qualitative methodology that enabled us to establish by visual inspection different levels of density of use. This methodology is based on the ability of an observer to identify patterns based on the dynamic inspection of an image bank. The beaches were divided into 3 zones: the paddling zone (the strip of beach where games are played and users enter and leave the sea), relaxation zone (the strip that is used most intensively, typically for sunbathing) and transit zone (the strip furthest from the shoreline, behind the relaxation zone, used for access to the beach, leaving and looking for a space in the sand), all of which were included in the evaluation. The density levels established for each of the beaches were as follows: 0 - null density, 0.5, 1, 1.5, 2, 2.5 and 3 - maximum density (see Fig. 2 for examples).

The densities of use were then related to different atmospheric elements to verify the human response to them or to endow each atmospheric scenario with tourist significance (de Freitas et al. 2004, MartínezIbarra 2010). To do this, we used daily information from the official meteorological or local government bodies (Table 3 ).

In selecting the meteorological variables, we have taken into consideration both the theoretical and methodological proposals of Besancenot $(1985,1989)$ and de Freitas (1990). Thus, in considering the ther-

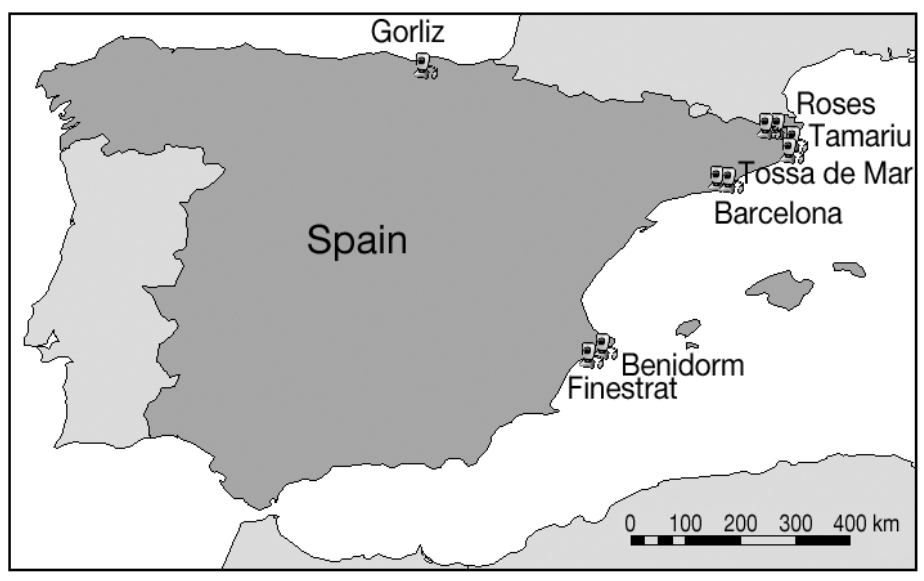

Fig. 1. The observation points selected 
Table 2. Characteristics of the beaches selected. All beaches were composed of golden sand, and offered the following facilities and services: toilets, showers, litter bins, cleaning service, and sunbed and sailboat rental

\begin{tabular}{|c|c|c|c|c|c|c|c|c|}
\hline & $\begin{array}{l}\text { St. Margarida, } \\
\text { Roses }\end{array}$ & Tamariu & $\begin{array}{c}\text { Gran, } \\
\text { Tossa de Mar }\end{array}$ & $\begin{array}{l}\text { Somorrostro, } \\
\text { Barcelona }\end{array}$ & $\begin{array}{c}\text { Nova Icaria, } \\
\text { Barcelona }\end{array}$ & $\begin{array}{l}\text { Levante, } \\
\text { Benidorm }\end{array}$ & Finestrat & $\begin{array}{l}\text { Gorliz, } \\
\text { Vizcaya }\end{array}$ \\
\hline \multicolumn{9}{|l|}{ General characteristics } \\
\hline Length $(\mathrm{m})$ & 700 & 220 & 385 & 1100 & 400 & 2000 & 300 & 842 \\
\hline Mean width (m) & 45 & 40 & 50 & 38 & 40 & 40 & 51 & 45 \\
\hline Level of occupancy & High & High & High & High & High & High & High & High \\
\hline Urban classification & Urban & Urban & Urban & Urban & Urban & Urban & Urban & Semi-urban \\
\hline Promenade & Yes & Yes & Yes & Yes & Yes & Yes & Yes & No \\
\hline \multicolumn{9}{|l|}{ Type of beach } \\
\hline Sea conditions & $\begin{array}{c}\text { Moderate } \\
\text { waves; windy }\end{array}$ & $\begin{array}{l}\text { Moderate } \\
\text { waves }\end{array}$ & $\begin{array}{c}\text { Moderate } \\
\text { waves }\end{array}$ & $\begin{array}{c}\text { Still } \\
\text { waters }\end{array}$ & $\begin{array}{c}\text { Still } \\
\text { waters }\end{array}$ & $\begin{array}{c}\text { Still } \\
\text { waters }\end{array}$ & $\begin{array}{c}\text { Still } \\
\text { waters }\end{array}$ & $\begin{array}{l}\text { Moderate } \\
\text { waves }\end{array}$ \\
\hline Mooring area & No & Yes & Yes & No & No & No & No & Yes \\
\hline Nudist & No & No & No & No & No & No & No & No \\
\hline \multicolumn{9}{|c|}{ Environmental characteristics } \\
\hline Presence of vegetation & Yes & Yes & No & No & No & No & Yes & Yes \\
\hline Protected zone & No & No & No & No & No & Yes & No & No \\
\hline Blue flag & Yes & Yes & Yes & Yes & Yes & Yes & Yes & No \\
\hline \multicolumn{9}{|l|}{ Safety and services } \\
\hline Lifeguard team & Yes & Yes & Yes & No & Yes & Yes & Yes & Yes \\
\hline Warning signs & Yes & Yes & Yes & No & Yes & Yes & Yes & Yes \\
\hline Local police & Yes & Yes & Yes & No & Yes & Yes & Yes & Yes \\
\hline Red Cross & Yes & Yes & Yes & No & Yes & Yes & Yes & Yes \\
\hline Coastguard & Yes & Yes & Yes & Yes & Yes & Yes & Yes & No \\
\hline Telephone & Yes & Yes & Yes & No & No & Yes & Yes & Yes \\
\hline Boardwalk access & Yes & Yes & Yes & Yes & Yes & Yes & Yes & No \\
\hline Parasols for rent & Yes & Yes & No & Yes & Yes & Yes & Yes & Yes \\
\hline Seaside kiosk & Yes & Yes & No & No & No & No & No & No \\
\hline Sailing club & No & Yes & Yes & No & No & No & No & No \\
\hline Diving zone & No & Yes & No & No & No & No & No & No \\
\hline $\begin{array}{l}\text { Municipal tourist } \\
\text { accommodation }\end{array}$ & 2006 & 2006 & 2006 & 2006 & 2006 & 2008 & 2008 & 2009 \\
\hline Hotels & 6786 & 1180 & 6942 & 46008 & 46008 & 39559 & 6980 & 30 \\
\hline Camp sites & 2101 & 3961 & 6554 & 0 & 0 & 11963 & 0 & 385 \\
\hline $\begin{array}{l}\text { Rural tourism } \\
\text { accommodation }\end{array}$ & 0 & 10 & 0 & 0 & 0 & 0 & 0 & 55 \\
\hline $\begin{array}{l}\text { No. second residences } \\
\text { (survey date) }\end{array}$ & $\begin{array}{l}17122 \\
(2001)\end{array}$ & $\begin{array}{l}7628 \\
(2001)\end{array}$ & $\begin{array}{c}4441 \\
(2001)\end{array}$ & $\begin{array}{l}57719 \\
(2001)\end{array}$ & $\begin{array}{l}57719 \\
(2001)\end{array}$ & $\begin{array}{l}18163 \\
(2008)\end{array}$ & $\begin{array}{l}23663 \\
(2008)\end{array}$ & $\begin{array}{l}1460 \\
(2001)\end{array}$ \\
\hline
\end{tabular}

mal conditions (thermal comfort), we selected ${ }^{1}$ maximum temperature $\left({ }^{\circ} \mathrm{C}\right)$, relative humidity $(\%)$ at 13:00 $\mathrm{h}$, solar radiation $\left(\mathrm{W} \mathrm{m}^{-2}\right)$ at 13:00 $\mathrm{h}$ and wind speed $\left(\mathrm{m} \mathrm{s}^{-1}\right)$ at 13:00 $\mathrm{h}$. This enabled us to calculate one of the most frequently used bioclimatic indices: the physiological equivalent temperature $\left(\mathrm{PET},{ }^{\circ} \mathrm{C}\right)$ (Höppe 1999, Matzarakis et al. 1999, Cegnar \& Matzarakis 2004). PET was calculated using the RayMan model (Matzarakis \& Rutz 2005). This model includes all of the significant variables that influence thermal comfort (Matzarakis et al. 2007). The variables comprise meteorological parameters, including air temperature, relative humidity, wind speed and solar

${ }^{1}$ Because the images were taken at noon, the meteorological data used were those that were recorded closest to that time and that were reliably provided by conventional and official weather stations radiation, and body parameters, including human activity, body heat production, and heat transfer in ${ }^{\circ} \mathrm{C}$. In considering the physical conditions (fundamental to understanding tourist satisfaction), we selected the wind speed at 13:00 $\mathrm{h}$, daily rainfall, the duration of the daily rainfall events, and the rainfall between 6:00 and 13:00 h. Finally, in considering the aesthetic conditions (or that of enjoyment), we selected the solar radiation at 13:00 $\mathrm{h}$.

\section{RESULTS AND DISCUSSION}

To analyse the descriptors (in this case, meteorological variables and the day of the week) that have an influence on the density of use of the beaches, we generated a parallel-coordinate graph. This method allows a rapid and effective analysis of large sets of 
Density 0

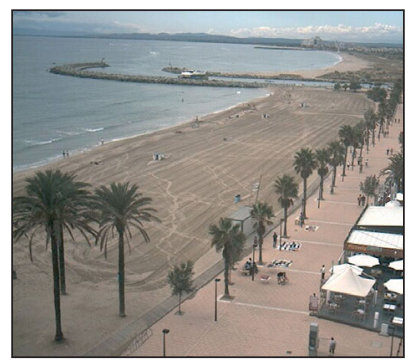

Density 0.5

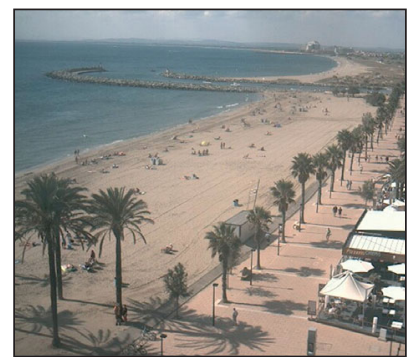

Density 1

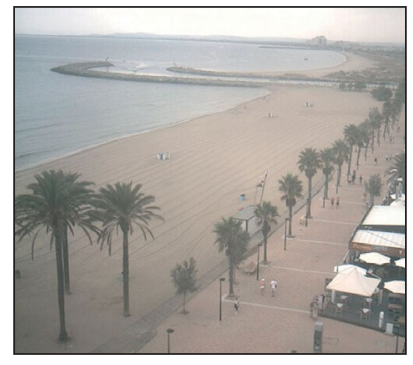

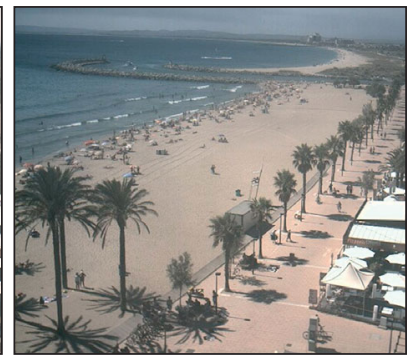

Density 1.5

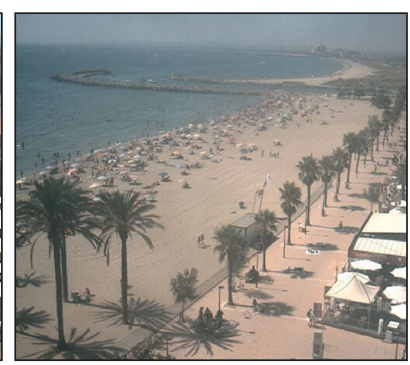

Density 2

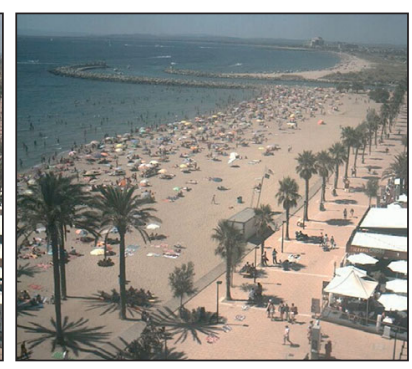

Density 2.5

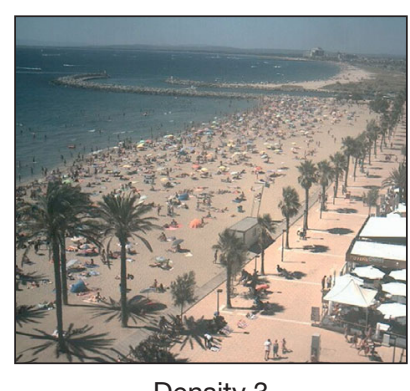

Density 3
Fig. 2. Example of densities of occupation at Santa Margarida Beach, Roses

n-dimensional data (of multiple variables) starting from the same pattern (the parallel axes that represent each variable have the same scale of reference, in our case lying between 0 and 1) (see Inselberg 1985, Wegman 1990, Eickemeyer et al. 1992). To do this, we divided the sample $(\mathrm{N}=782)$ into 2 representative groups (occupancy levels $<2$ and $\geq 2$ ) (Table 4 ).

Based on Fig. 3 and the numerical results, we conclude that the factors that had the most impact on the daily use of the beaches were, in order of importance, the solar radiation at 13:00 $\mathrm{h}$, maximum PET value, maximum temperature and the fraction of radiation at 13:00 h. The day of the week (the study was focused primarily on the summer months) was of only secondary importance. Two further factors were found to have very little significance: the daily rainfall totals and daily duration of precipitation events (which were negative factors for beach use) and the wind speed at 13:00 h (likely due to the rarity of days on which the wind speed was of any note). The importance of thermal comfort and solar radiation for sun and beach tourism corroborates the results obtained through surveys conducted with students, for this same type of tourism, by de Freitas et al. (2008) and Scott et al. (2008).

If the comparative analysis is conducted for pairs (density paired with meteorological variables or day of the week), and we analyse the Pearson correlation (r) and determination coefficients $\left(\mathrm{R}^{2}\right)$, the results are fairly similar. Thus, in agreement with these findings, the variables that are most closely related to beach occupancy levels were the maximum temperature, PET and solar radiation at 13:00 $\mathrm{h}$. These were followed, albeit at some distance, by the fraction of radiation at 13:00 $\mathrm{h}$, and the duration of daily precipitation events was even less correlated. In contrast, the daily rainfall, morning rainfall, day of the week and wind speed were not very representative (Table 4). The low correlation between beach occupancy and the day of the week during the summer holiday period as mentioned by Sinclair-Hannocks (1994) and Moreno \& Amelung (2009) can also be extrapolated to our study.

The behavioural analysis of the distribution (concentration-dispersion) of the values of the meteorological variables categorised by groups of density use, was opportune for identifying the most appropriate meteorological thresholds for going to the beach. The mean of maximum daily temperature increased as we reached values of density use equal to 2 (Table 5). Thus, it seems that the optimum maximum temperature for going to the beach lies between 28.8 and $31^{\circ} \mathrm{C}$. These results agree with those of Martínez-Ibarra (2008) and Moreno \& Amelung (2009). In addition, the lowest maximum daily temperature corresponding to densities of at least 1.5 was $18.7^{\circ} \mathrm{C}$. Martínez-Ibarra (2008) proposed a threshold for the lowest maximum daily temperature of $18^{\circ} \mathrm{C}$ for tourists going to the Levante Beach in Benidorm.

The affinity between the density of use and the PET is reminiscent of that mentioned above for the maximum temperature. Here, the mean values also increased up to beach densities of 2 (Table 5). Thus, the optimum PET value for going to the beach ranges between 34.5 and $38.8^{\circ} \mathrm{C}$. The lowest value guaranteeing a level of occupancy of at least 1.5 was $15.9^{\circ} \mathrm{C}$. 
Table 3. Weather stations selected

\begin{tabular}{|c|c|c|c|c|c|}
\hline Beach & Geographical coordinates & Weather station & Geographical coordinates & Alt. (m) & Agency \\
\hline St. Margarida, Roses & $42^{\circ} 15^{\prime} 42^{\prime \prime} \mathrm{N}_{;} 03^{\circ} 09^{\prime} 12^{\prime \prime} \mathrm{E}$ & Roses & $42^{\circ} 16^{\prime} 20^{\prime \prime} \mathrm{N}_{;} 03^{\circ} 10^{\prime} 58^{\prime \prime} \mathrm{E}$ & 24 & (1) \\
\hline Tamariu, Tamariu $^{\mathrm{a}}$ & $41^{\circ} 55^{\prime} 04^{\prime \prime} \mathrm{N}_{i} 03^{\circ} 12^{\prime} 28^{\prime \prime} \mathrm{E}$ & $\begin{array}{l}\text { Castell d' Aro } \\
\text { L' Estartit }\end{array}$ & $\begin{array}{l}41^{\circ} 48^{\prime} 37^{\prime \prime} \mathrm{N}_{;} 03^{\circ} 02^{\prime} 00^{\prime \prime} \mathrm{E} \\
42^{\circ} 03^{\prime} 18^{\prime \prime} \mathrm{N}_{;} 03^{\circ} 12^{\prime} 10^{\prime \prime} \mathrm{E}\end{array}$ & $\begin{array}{c}14 \\
2\end{array}$ & $\begin{array}{l}(1) \\
(2)\end{array}$ \\
\hline Gran, Tossa de Mar ${ }^{\mathrm{a}}$ & $41^{\circ} 43^{\prime} 08^{\prime \prime} \mathrm{N}_{i} 02^{\circ} 56^{\prime} 01^{\prime \prime} \mathrm{E}$ & $\begin{array}{l}\text { Blanes } \\
\text { Castell d' Aro }\end{array}$ & $\begin{array}{l}41^{\circ} 40^{\prime} 41^{\prime \prime} \mathrm{N}_{;} 02^{\circ} 48^{\prime} 23^{\prime \prime} \mathrm{E} \\
41^{\circ} 48^{\prime} 37^{\prime \prime} \mathrm{N}_{;} 03^{\circ} 02^{\prime} 00^{\prime \prime} \mathrm{E}\end{array}$ & $\begin{array}{l}26 \\
14\end{array}$ & $\begin{array}{l}(2) \\
(1)\end{array}$ \\
\hline Somorrostro, Barcelona & $41^{\circ} 23^{\prime} 01^{\prime \prime} \mathrm{N}_{i} 02^{\circ} 11^{\prime} 44^{\prime \prime} \mathrm{E}$ & Barcelona CMT & $41^{\circ} 23^{\prime} 27^{\prime \prime} \mathrm{N}_{i} 02^{\circ} 12^{\prime} 05^{\prime \prime} \mathrm{E}$ & 21 & $(2)$ \\
\hline Nova Icaria, Barcelona & $41^{\circ} 23^{\prime} 26^{\prime \prime} \mathrm{N}_{i} 02^{\circ} 12^{\prime} 08^{\prime \prime} \mathrm{E}$ & Barcelona CMT & $41^{\circ} 23^{\prime} 27^{\prime \prime} \mathrm{N}_{;} 02^{\circ} 12^{\prime} 05^{\prime \prime} \mathrm{E}$ & 21 & $(2)$ \\
\hline Levante, Benidorm & $38^{\circ} 32^{\prime} 21^{\prime \prime} \mathrm{N}_{i} 0^{\circ} 07^{\prime} 71^{\prime \prime} \mathrm{W}$ & Benidorm & $38^{\circ} 32^{\prime} 22^{\prime \prime} \mathrm{N}_{;} 0^{\circ} 7^{\prime} 43^{\prime \prime} \mathrm{W}$ & 22 & (3) \\
\hline Finestrat & $38^{\circ} 31^{\prime} 29^{\prime \prime} \mathrm{N}_{i} 0^{\circ} 10^{\prime} 01^{\prime \prime} \mathrm{W}$ & Benidorm & $38^{\circ} 32^{\prime} 22^{\prime \prime} \mathrm{N}_{i} 0^{\circ} 7^{\prime} 43^{\prime \prime} \mathrm{W}$ & 22 & (3) \\
\hline Gorliz $^{\mathrm{a}}$ & $43^{\circ} 24^{\prime} 48^{\prime \prime} \mathrm{N}_{i} 02^{\circ} 56^{\prime} 42^{\prime \prime} \mathrm{W}$ & $\begin{array}{l}\text { Lequeitio } \\
\text { Mungia }\end{array}$ & $\begin{array}{l}43^{\circ} 22^{\prime} 37^{\prime \prime} \mathrm{N} ; 02^{\circ} 30^{\prime} 40^{\prime \prime} \mathrm{W} \\
43^{\circ} 21^{\prime} 48^{\prime \prime} \mathrm{N}_{;} 02^{\circ} 50^{\prime} 41^{\prime \prime} \mathrm{W}\end{array}$ & $\begin{array}{l}12 \\
12\end{array}$ & $\begin{array}{l}(2) \\
(4)\end{array}$ \\
\hline
\end{tabular}

Both the optimum threshold and the lower limit corroborate the results obtained by Martínez-Ibarra (2010).

The median percentage values of solar radiation at 13:00 h increased up to occupancy levels of at least 1.5, and the mean increased up to values of at least 2 . The inter-quartile limits fell markedly up to occupancy levels of 2, remaining, after this threshold, between 9 and $15 \%$. The lower limit of the second quartile was highly representative (Table 5). The lowest values are also relevant, and for occupancy levels of at least 2, only in $2.6 \%$ of cases $(\mathrm{N}=389)$ were radiation values $<50 \%$ recorded.

In the case of wind speed at 13:00 h, the homogeneity of values reflects the season. It is, therefore, more appropriate to analyse the extreme values (specifically at the upper end). Velocities $>10 \mathrm{~m} \mathrm{~s}^{-1}$ were never recorded for densities $\geq 2$ and velocities $>8 \mathrm{~m} \mathrm{~s}^{-1}$ for densities $\geq 2$ were only reached in $2.4 \%(\mathrm{~N}=376)$ of cases. The maximum accepted limit in the classifications of weather types suitable for sun and beach tourism is $10 \mathrm{~m} \mathrm{~s}^{-1}$ (MartínezIbarra 2008, 2010).

The absence of summer rainfall events in most of the areas considered here also makes it more relevant to study the extreme values. Thus, for $77 \%$ of the days for which data were collected, no rainfall was recorded $(\mathrm{N}$
= 807). Here, we can associate the lower frequency of atypical values both for duration, quantity of daily rainfall and quantity of morning rainfall to densities $\geq 2$. Thus, the daily rainfall, morning rainfall and duration of daily rainfall limits were below $3.9 \mathrm{~mm}$,

Table 4. Descriptors of beach use for the 2 groups of density considered (occupancy levels $<2$ and $\geq 2$ ), and correlations between density of use and atmospheric conditions. PET: physiological equivalent temperature; r: Pearson correlation; $\mathrm{R}^{2}$ : determination coefficient; $\mathrm{N}$ : no. of measurements

\begin{tabular}{|lcccccc|}
\hline \multirow{2}{*}{ Descriptors } & \multicolumn{5}{c}{ Occupancy levels } \\
\cline { 2 - 6 } & $<2$ & $\geq 2$ & $\mathrm{r}$ & $\mathrm{R}^{2}$ & $\mathrm{~N}$ \\
\hline Day of the week & 0.46 & 0.54 & 0.1 & 0.0 & 819 \\
Maximum temperature $\left({ }^{\circ} \mathrm{C}\right)$ & 0.38 & 0.57 & 0.7 & 0.48 & 816 \\
Maximum PET value $\left({ }^{\circ} \mathrm{C}\right)$ & 0.40 & 0.61 & 0.7 & 0.48 & 816 \\
Solar radiation at $13: 00 \mathrm{~h}\left(\mathrm{~W} \mathrm{~m}^{-2}\right)$ & 0.55 & 0.77 & 0.7 & 0.44 & 810 \\
Wind speed at 13:00 $\mathrm{h}\left(\mathrm{m} \mathrm{s}^{-1}\right)$ & 0.38 & 0.41 & 0.1 & 0.0 & 819 \\
Daily precipitation $(\mathrm{mm})$ & 0.02 & 0.00 & 0.2 & 0.1 & 812 \\
Duration of daily precipitation $(\mathrm{min})$ & 0.06 & 0.01 & 0.3 & 0.1 & 816 \\
Morning precipitation $(\mathrm{mm})$ & 0.01 & 0.00 & 0.2 & 0.0 & 813 \\
Fraction of solar radiation at 13:00 h $(\%)$ & 0.71 & 0.86 & 0.4 & 0.2 & 810 \\
\hline
\end{tabular}

Table 5. Densities of beach use, and limits of the 3rd quartile of maximum daily temperature and physiological equivalent temperature (PET), and lower limit of the 2 nd quartile of solar radiation at 13:00 h. N: no. of measurements

\begin{tabular}{|lrrrrrr|}
\hline \multirow{2}{*}{ Density } & \multicolumn{2}{c}{ Mean max. temp. } & \multicolumn{2}{c}{ - Mean PET - } & \multicolumn{2}{c|}{ Median radiation } \\
& Range $\left({ }^{\circ} \mathrm{C}\right)$ & $\mathrm{N}$ & Range $\left({ }^{\circ} \mathrm{C}\right)$ & $\mathrm{N}$ & Limit $(\%)$ & $\mathrm{N}$ \\
\hline 0 & $20.8-23.5$ & 129 & $19.8-23.0$ & 109 & 30.0 & 111 \\
0.5 & $25.0-26.3$ & 95 & $26.6-29.8$ & 105 & 57.6 & 107 \\
1 & $25.6-27.5$ & 110 & $28.6-31.6$ & 106 & 64.7 & 106 \\
1.5 & $27.3-28.7$ & 98 & $32.0-34.5$ & 97 & 76.6 & 95 \\
2 & $28.8-30.9$ & 154 & $34.5-37.8$ & 162 & 82.1 & 163 \\
2.5 & $29.2-30.6$ & 116 & $34.8-37.4$ & 104 & 85.8 & 107 \\
3 & $29.5-31.0$ & 114 & $35.8-38.8$ & 110 & 79.5 & 119 \\
\hline
\end{tabular}



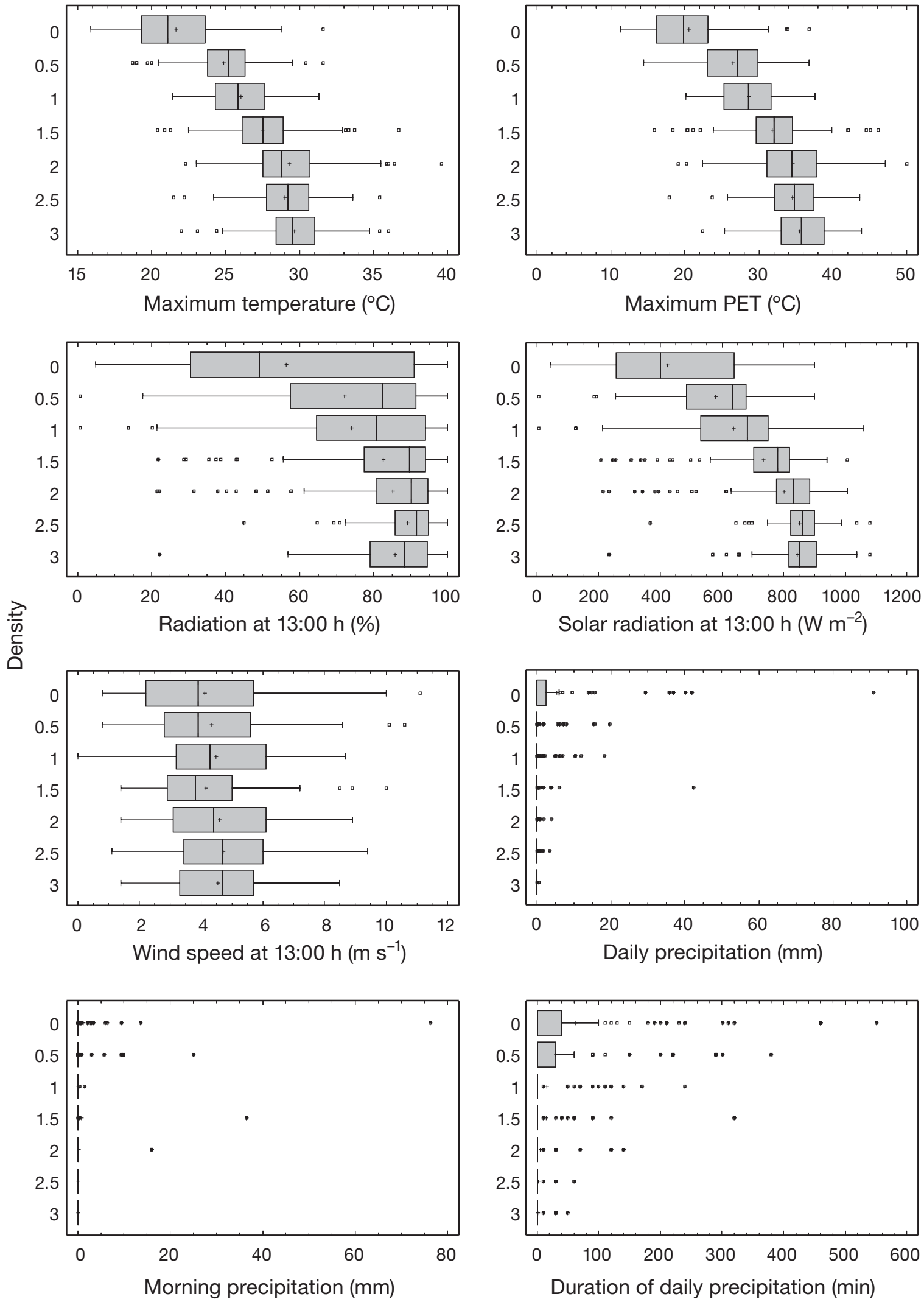

Fig. 3. Density of use on the beaches analysed and the values of the meteorological variables considered. PET: physiological equivalent temperature. Cross: mean; central line in box: median; box: 1st and 3rd quartiles; symbols outside box: atypical values 
$3.9 \mathrm{~mm}$ and $140 \mathrm{~min}(\mathrm{~N}=812, \mathrm{~N}=813$ and $\mathrm{N}=807)$, respectively. For these densities of use $(\geq 2)$, the values were $>0$ (mm and $\mathrm{min}$ ) in $16 \%, 15.7 \%$ and $9.2 \%$ of the cases, respectively. If we consider values of at least $1 \mathrm{~mm}$ or a duration of at least $60 \mathrm{~min}$, these percentages rise to $9.7 \%, 7.7 \%$ and $4.6 \%$, in each case. Thus, there should be no precipitation or levels should not exceed $1 \mathrm{~mm}$ and precipitation, events should not last for >60 min (Besancenot 1989).

\section{CONCLUSIONS}

Systems of information capture that use stationary cameras connected to computerised systems, which also allow the transmission of live images via Internet, open the door to new methods of obtaining quantitative and qualitative data to describe different aspects of the tourist phenomenon. Webcams and video systems are good instruments for studying the influence of atmospheric conditions on the behaviour of tourist demand. The information these systems provide, when treated with rigour and complemented by other more traditional systems, such as visual counting, the use of photographs and the conducting of surveys and interviews, can shed considerable light on one of the many aspects involved in the decision-making processes of the tourist-consumer, which, in turn, can be of use to the experts and managers in a given region or in relation to a given tourist activity. Thus, the determination of the temporal and spatial distribution of the habits of sun and beach tourists (seen here as motor responses to the stimuli of the weather and climate) and possible modifications of this behaviour as a function of the variability in atmospheric conditions should be of use in short-, medium- and long-term coastal management plans.

Atmospheric conditions have an effect on the behaviour of sun and beach tourists, and our study has shown that the density of use of the beaches in Spain is controlled principally by solar radiation (the aesthetic facet) as well as the maximum temperature and the PET (the comfort facet). According to our results, the optimal thresholds of these meteorological variables for going to the beach are as follows: a maximum temperature between 28.83 and $31^{\circ} \mathrm{C}_{\text {; }}$ a maximum PET between 34.5 and $38.8^{\circ} \mathrm{C}$; a percentage of solar radiation at $13: 00 \mathrm{~h}$ of at least $50 \%$; a wind speed at 13:00 h of $<8 \mathrm{~m} \mathrm{~s}^{-1}$ (or, at the most, $<10 \mathrm{~m} \mathrm{~s}^{-1}$ ); and no rainfall or, at the most $<1 \mathrm{~mm} \mathrm{~d}^{-1}$ or a rainfall event with a duration of $<60 \mathrm{~min}$.

The application of these thresholds for determining the degree of use of the beaches during the year should help forecast more accurately the calendar of the tourist season and ensure that the basic tourist resources provided for beach tourism are managed more effectively during these periods (thus avoiding their degradation or deterioration as far as possible), including the provision of services (boardwalks, showers, toilets, cleaning services, etc.) and safety facilities (lifeguards, first aid centres, coastguards, warning signs, etc.). These features are essential for maintaining and improving the use of these leisure and recreational areas, satisfying the needs of tourists and conserving the elements that have facilitated the appearance and development of this tourist activity. However, we should point out that there are other aspects of behaviour that have not been approached here but which deserve further study to improve our understanding of the behaviour of sun and beach tourists in relation to atmospheric parameters. We refer to such questions as the localisation of the users on the beach, activities performed while they are on the beach (e.g. sunbathing, bathing in the water, hiring small boats or playing ball games), evolution of the density of use throughout the day and other factors.

In the medium- and long-term, our study highlights the fact that the behaviour patterns of sun and beach tourists in relation to weather conditions could act to reduce the magnitude of the impact of climate change on this particular tourist activity, thereby allowing Spain's Mediterranean coast to maintain its position as a leader in this region. The analysis of the behaviour of sun and beach tourists in relation to weather conditions reveals that they are prepared to tolerate weather conditions that differ from those considered optimal for this activity (Morgan et al. 2000, Gómez-Martín 2006, Scott et al. 2008), with thresholds of tolerance being especially marked in the case of maximum temperatures. A number of forecasts, based solely on analyses of preference (Amelung et al. 2007, Hein et al. 2009) as opposed to behaviour, predict a loss of tourist-climate aptitude for Spain's Mediterranean coast in the summer because of the increase in temperatures and the lowering of comfort indices. However, the inclusion in these forecasts of atmospheric tolerance thresholds (derived from the observation of behaviour) could introduce notable signs of optimism for the future of tourism on Spain's beaches: the consideration of atmospheric tolerance thresholds in analyses of future tourist-climate potential could indicate a possible intensification of sun and beach tourism in the study area given that the reduction in tourist-climate aptitude might not be as marked as that predicted by preference analyses. The consideration of the 'be- 
haviour' variable could give rise to new future scenarios for tourism on Spain's Mediterranean beaches, and these need to be taken into account in the management and planning of the country's coastline.

Acknowledgements. This study was conducted within the framework of a Plan Nacional de I+D+I research project sponsored by Spain's Ministerio de Ciencia e Innovación, reference number CSO2008-01346. The images of Barcelona's city beaches are from the Coastal Ocean Observatory (http://coo.icm.csic.es/) of the Institute of Marine Sciences of the Spanish National Research Council (ICM-CSIC). We especially thank the 3 anonymous reviewers who helped us to improve our manuscript.

\section{LITERATURE CITED}

Adams RDL (1973) Uncertainty in nature, cognitive dissonance, and the perceptual distortion of environmental information: weather forecasts and New England beach trip decisions. Econ Geogr 49:287-297

- Agnew M, Palutikof J (2006) Impacts of short-term climate variability in the UK on demand for domestic and international tourism. Clim Res 31:109-120

> Álvarez-Díaz M, Otero S, González-Gómez M (2010) Statistical relationships between the North Atlantic Oscillation and international tourism demand in the Balearic Islands, Spain. Clim Res 43:207-214

Amelung B, Nicholls S, Viner D (2007) Implications of global climate change for tourism flows and seasonality. J Travel Res 45:285-296

Besancenot JP (1985) Clima et tourisme estival sur les côtes de la péninsule Ibérique. Rev Geogr Pyren Sud Ouest 56: 427-451

Besancenot JP (1989) Clima et turisme. Masson, Paris

> Bigano A, Hamilton J, Tol RSJ (2006) The impact of climate on holiday destination choice. Clim Chang 76:389-406

Butler R (2001) Seasonality in tourism: issues and implications. In: Baum $\mathrm{T}$, Lundtorp $\mathrm{S}$ (eds) Seasonality in Tourism. Pergamon, London, p 5-22

Cegnar T, Matzarakis A (2004) Climate and bioclimate variations in Slovenia and their application for tourism. In: Matzarakis A, de Freitas CR, Scott D (eds) Advances in tourism climatology, No. 12. Ber Meteorol Inst Univ Freiburg, Freiburg, p 66-73

> Coombes EG, Jones AP, Sutherland WJ (2009) The implications of climate change on coastal visitor numbers: a regional analysis. J Coast Res 25:981-990

> Crouch GI (1994) The study of international tourism demand: a survey of practice. J Travel Res 32:41-54

de Freitas CR (1990) Recreation climate assessment. Int J Climatol 10:89-103

de Freitas CR (2003) Tourism climatology: evaluating environmental information for decision making and business planning in the recreation and tourism sector. Int J Biometeorol 48:45-54

de Freitas CR (2008) New generation tourism climate indicators: assessing climate and climate preferences and sensitivity as factors in tourism demand. In: Proc 18th Int Congr Biometeorol, Sep. 22-26, Tokyo, Japan

de Freitas CR, Scott D, McBoyle G (2004) A new generation climate index for tourism. In: Matzarakis A, de Freitas CR, Scott D (eds) Advances in tourism climatology, No.
12. Ber Meteorol Inst Univ Freiburg, Freiburg, p 19-26

de Freitas CR, Scott D, McBoyle G (2008) A second generation climate index for tourism (CIT): specification and verification. Int J Biometeorol 52:399-407

Eickemeyer JS, Inselberg A, Dimsdale B (1992) Visualizing p-flats in n-space using parallel coordinates. Technical Report G320-3581, IBM Palo Alto Scientific Center.

Eliasson I, Knez I, Westerberg U, Thorsson S, Lindberg F (2007) Climate and behaviour in a Nordic city. Landsc Urban Plan 82:72-84

Eymann A, Ronning G (1997) Microeconometric models of tourists' destination choice. Reg Sci Urban Econ 27: $735-761$

Gómez-Martín MB (2005) Weather, climate and tourism: a geographical perspective. Ann Tourism Res 32:571-591

Gómez-Martín MB (2006) Climate potential and tourist demand in Catalonia (Spain) during the summer season. Clim Res 32:75-87

Guillén J, García A, Ojeda E, Osorio A, Chic O, González R (2008) Long-term quantification of beach users using video monitoring. J Coast Res 24:1612-1619

> Hamilton J, Maddison D, Tol R (2005) Effects of climate change on international tourism. Clim Res 29:245-254

Hein L, Metzger MJ, Moreno A (2009) Potential impacts of climate change on tourism: a case study for Spain. Curr Opinion Environ Sustainabil 1:170-178

Holland KT, Holman RA, Lippman TC, Stanley J, Plant N (1997) Practical use of video imagery in nearshore oceanographic field studies. IEEE J Ocean Eng 22:81-92

Holman RA, Sallenger AH, Lippmann TCD, Haines JW (1993) The application of video image processing to the study of nearshore processes. Oceanography 6:78-85

> Höppe P (1999) The physiological equivalent temperature a universal index for the bio-meteorological assessment of the thermal environment. Int J Biometeorol 43:71-75

> Hu Y, Ritchie J (1993) Measuring destination attractiveness: a contextual approach. J Travel Res 32:25-34

> Inselberg A (1985) The plane with parallel coordinates. Vis Comput 1:69-91

> Jiménez JA, Osorio A, Marino-Tapia I, Davidson M and 5 others (2007) Beach recreation planning using videoderived coastal state indicators. Coast Eng 54:507-521

Kammler M, Schernewski G (2004) Spatial and temporal analysis of beach tourism using webcam and aerial photographs. In: Schernewski G, Löser, N (eds) BaltCoast 2004 - Managing the Baltic Sea. Coastline Rep 2: 121-128

Kotler P, Bowen J, Makens J (1996) Marketing for hospitality and tourism. Prentice Hall, Upper Saddle River, NJ

> Lim C (1997) Review of international tourism demand models. Ann Tourism Res 24:835-849

> Lin TP (2009) Thermal perception, adaptation and attendance in a public square in hot and humid regions. Build Environ 44:2017-2026

Lise W, Tol RSJ (2002) Impact of climate on tourist demand. Clim Change 55:429-449

Martínez-Ibarra E (2008) Tipos de tiempo para el turismo de sol y playa en el litoral alicantino. Estud Geogr 69: 135-155

Martínez-Ibarra E (2010) The use of webcam images to determine tourist-climate aptitude: favourable weather types for sun and beach tourism on the Alicante coast (Spain). Int J Biometeorol 55:373-385 doi:10.1007/ s00484-010-0347-8

Matzarakis A, Rutz F (2005) Application of RayMan for 
tourism and climate investigations. Ann Meteorol N F 41: 631-636

Matzarakis A, Mayer H, Iziomon MG (1999) Applications of a universal thermal index: physiological equivalent temperature. Int J Biometeorol 43:76-84

Matzarakis A, Rutz F, Mayer H (2007) Modelling radiation fluxes in simple and complex environments-application of the RayMan model. Int J Biometeorol 51:323-334

Melenberg B, Van Soest A (1996) Parametric and semi-parametric modelling of vacation expenditures. J Appl Econ 11:59-76

Moreno A, Amelung B (2009) Climate change and tourist comfort on Europe's beaches in summer: a reassessment. Coast Manage 37:550-568

Moreno A, Amelung B, Santamarta L (2008) Linking beach recreation to weather conditions: a case study in Zandvoort, Netherlands. Tour Mar Environ 5:111-120

Morgan R, Gatell E, Junyent R, Micallef A, Özhan E, Williams AT (2000) An improved user-based beach climate index. J Coast Conserv 6:41-50

Moutinho L (1987) Consumer behaviour in tourism. Eur J Market 21:5-44

Nikolopoulou M, Baker N, Steemers K (2001) Thermal comfort in outdoor urban spaces: understanding the human parameter. Sol Energy 70:227-235

Pack A, Clewer A, Sinclair MT (1995) Regional concentration and dispersal of tourism demand in the UK. Reg Stud 29:570-576

Pearce PL (2005) Tourist behaviour. Channel View Publications, Bristol

Pizan A, Mansfeld Y (eds) (1999) Consumer behaviour in travel and tourism. Routledge, New York

Scott D, Lemieux C (2009) Weather and climate information for tourism. White Paper, World Meteorological Organisation, Geneva

Editorial responsibility: Helmut Mayer, Freiburg, Germany
Scott D, Gossling S, de Freitas CR (2008) Preferred climates for tourism: case studies from Canada, New Zealand and Sweden. Clim Res 38:61-73

Sinclair-Hannocks S (1994) Sustainable ecological and recreational management of sandy beach systems. PhD dissertation, University of Technology, Sydney

Smeral E, Witt SF (1996) Econometric forecasts of tourism demand to 2005. Ann Tourism Res 23:891-907

Song H, Li G (2008) Tourism demand modelling and forecasting - a review of recent research. Tourism Manage 29:203-220

Swarbrooke T, Horner S (1999) Consumer behaviour in tourism. Butterworth-Heinemann, Oxford

> Thorsson S, Lindqvist M, Lindqvist S (2004) Thermal bioclimatic conditions and patterns of behaviour in an urban park in Göteborg, Sweden. Int J Biometeorol 48: 149-156

Thorsson S, Honjo T, Lindberg F, Eliasson I, Lim EM (2007) Thermal comfort and outdoor activity in Japanese urban public places. Environ Behav 39:660-684

Timothy DJ, Groves DL (2001) Research note: webcam images as potential data sources for tourism research. Tourism Geogr 3:394-404

Wang CH (2004) Predicting tourism demand using fuzzy time series and hybrid grey theory. Tourism Manage 25: 367-374

> Wegman EJ (1990) Hyperdimensional data analysis using parallel coordinates. J Am Stat Assoc 85:664-675

Witt SF, Witt CA (1995) Forecasting tourism demand: A review of empirical research. Int J Forecasting 11:447-475

WTO (World Tourism Organization) (2010a) Tourism highlights 2009. WTO, Madrid

WTO (World Tourism Organization) (2010b) Barómetro, Junio 2010. WTO, Madrid

Submitted: May 27, 2011; Accepted: October 27, 2011 Proofs received from author(s): February 27, 2012 